\title{
0 Brasil deve restringir a experimentação com animais?
}

Luiz Eugênio Araújo de Moraes Mello

$\mathrm{L}$ egalizar sim, restringir não. Na maioria dos casos não faltam leis no Brasil, falta sim fiscalização e aplicação de punições para quem as descumpre. No caso da experimentação com animais temos um fato pouco freqüente no Brasil. Faltam leis e regulamentações sobre o assunto. Interessante que nesse caso, também ao contrário da regra acima exposta, já há até um grau razoável de fiscalização. Em 1995, há portanto 12 anos atrás, o Deputado Federal Sergio Arouca, já falecido, propôs uma lei regulamentando o uso de animais de experimentação. Essa lei foi amplamente discutida com a comunidade científica e após passar por várias Comissões da Câmara dos Deputados, aguarda agora sua votação no plenário. Como se vê, ainda não foi votada. Ainda não é uma lei, mas é uma proposta lógica, adequada, importante e necessária. Assim é que todas, note bem, todas as principais universidades e instituições de ensino e pesquisa de qualidade do país já adotam a lei. Todas essas instituições já têm uma Comissão de Ética que avalia os procedimentos. Em todas, a Comissão de Ética já é composta por membros da comunidade acadêmica e por integrantes da sociedade, de forma ampla.

Porquê então votar uma lei, se mesmo sem uma lei votada já se segue a regra? Porque é importante haver leis. Porque mesmo que mais de $90 \%$ da pesquisa do país tenha origem em instituições que já se adequam a futura lei, é certo que há abusos. As leis não impedem abusos, mas permitem punir quem os comete. Precisamos sim de uma lei, de uma lei sensata, que coíba abusos e que permita o avanço do conhecimento; que enfatize a restrição do número de animais utilizados; a busca de métodos alternativos; a minimização de todo e qualquer sofrimento. A sociedade não pode ignorar os avanços e os benefícios do conhecimento. Devemos impedir que as pessoas andem de carro porque alguns loucos matam pessoas ao dirigir embriagados? Ou devemos fazer leis que ao punir quem dirige embriagado, coíbam essa ação? Devemos sim, educar, conscientizar e fazer entender que a experimentação científica com animais de laboratório é importante; traz luz ao mundo, nos permite entender o que somos e como somos; nos permite prevenir doenças; curar, tratar e prolongar a vida. Nos permite preservar o mundo em que vivemos ao entendermos a interação entre as espécies; ao entender quais animais comem quais sementes; quais ecossistemas são ameaçados por desequilíbrios de quais elementos animais ou vegetais. Há plantas, animais e doenças típicas do Brasil que não existem ou são pouco freqüentes em outros lugares. Como vamos curar ou tratar essas doenças, como vamos proteger esses animais se não pudermos compreendê-los?

A ausência de leis no Brasil cria um ambiente propício para as mais estapafúrdias proposições. Precisamos de leis e precisamos delas já. A pesquisa científica brasileira coloca o país na $15^{a}$ posição entre as nações com mais expressiva atividade científica. Só seremos um país grande, livre e soberano se pudermos pesquisar nossos recursos e nossos interesses. A pesquisa biomédica tem imenso potencial em nosso país. Fazemos protocolos únicos no mundo, pioneiros. Avançamos pelas fronteiras da ciência porque fazemos de acordo com preceitos modernos de qualidade e ética. A pesquisa biomédica brasileira seria execrada se não estivesse de acordo com as normas internacionais.

Não podemos permitir que o obscurantismo caia sobre o Brasil. Não podemos permitir que meias verdades resultem no inexorável sofrimento a que estaremos condenados com a ausência de experimentação animal. Como saber que um novo composto é tóxico? Como saber que a tinta ou o plástico usado nos brinquedos de nossos filhos não é tóxico? Como garantir a eficácia e a segurança da vacina contra gripe feita todo ano? Notem que essa vacina é feita contra os sorotipos presentes no Brasil no ano anterior. Vamos tomar vacina contra o sorotipo chinês ou europeu?

Só uma visão míope do mundo pode considerar factível um Brasil sem experimentação animal. No mundo real e em todos os países civilizados do mundo a experimentação animal é não apenas legítima, como apoiada por esses países. 